\title{
Anti Acne Vulgaris Topical Cream From Combination Extract of Gymnanthemum Amygdalinum Del. and Elaeis Guineensis Jacq. Leaves
}

\author{
Wahyudi, Ayu Syahfitri, Firdaus Fahdi, Syukur Berkat Waruwu and Dian Ika \\ Perbina \\ Department of Pharmaceutical, Faculty of Pharmacy, Institut Kesehatan Deli Husada Deli Tua, \\ Indonesia
}

\begin{abstract}
Acne is one problem in adolescents and adults who can reduce self-confidence. This study aimed to formulate the combination cream of African leaf extract and palm oil leaves to determine the antibacterial activity of African leaf extract against several acne-causing bacteria (Propionibacterium acne and Staphylococcus epidermidis). Test antibacterial activity of extracts and cream with disc diffusion method. The cream is made with concentration of 5, 10 and $20 \%$ w/w. The evaluation results of cream with concentration of 5, 10 and $20 \%$ were physically stable for 4 weeks of storage at temperature room, homogeneous, $\mathrm{pH}$ and it did not cause irritation. Based on the test results, a combination of African leaf extract with concentration of $5 \%$ effectively inhibited bacterial growth with an average inhibition zone diameter of $12.06 \mathrm{~mm}$ for Propionibacterium acne bacteria and $13.63 \mathrm{~mm}$ for Staphylococcus epidermidis bacteria. The result of this study suggest that combination of African leaf extract and palm leaves posses potent antibacterial activity against Propionibacterium acne and Staphylococcus epidermidis.
\end{abstract}

Keywords : Acne Vulgaris., Elaeis guineensis Jacq., Gymnanthemum amygdalinum Del., Topical Cream.

\begin{abstract}
Abstrak. Jerawat adalah salah satu masalah pada remaja dan orang dewasa yang dapat mengurangi rasa percaya diri. Penelitian ini bertujuan untuk memformulasikan krim kombinasi ekstrak daun Afrika dan daun kelapa sawit untuk menentukan aktivitas antibakteri ekstrak daun Afrika terhadap beberapa bakteri penyebab jerawat (Propionibacterium acne dan Staphylococcus epidermidis). Uji aktivitas antibakteri ekstrak dan krim dengan metode difusi cakram. Krim dibuat dengan konsentrasi 5, 10 dan 20\%. Hasil evaluasi krim dengan konsentrasi 5, 10 dan 20\% stabil secara fisik selama 4 minggu penyimpanan pada suhu kamar, semua sediaan krim homogen, pH krim sekitar 6-6,5 dan sediaan krim yang diformulasikan tidak menyebabkan iritasi pada kulit. Berdasarkan hasil pengujian sediaan krim dengan konsentrasi 5\% secara efektif menghambat pertumbuhan bakteri dengan diameter zona hambat rata-rata 12,06 mm untuk bakteri Propionibacterium acne dan 13,63 mm untuk bakteri Staphylococcus epidermidis. Kesimpulan dari penelitian ini adalah semua sediaan krim kombinasi ekstrak daun Afrika dan daun kelapa sawit memiliki aktivitas antibakteri terhadap Propionibacterium acne dan Staphylococcus epidermidis.
\end{abstract}

Kata kunci: Elaeis Guineensis Jacq., Gymnanthemum Amygdalinum Del., Jerawat., Krim Topikal.

Received 4 June 2020 | Revised 26 June 2020 | Accepted 28 July 2020.

\footnotetext{
*Corresponding author at:Department of Pharmaceutical, Faculty of Pharmacy, Institut Kesehatan Deli Husada Deli Tua, Indonesia

E-mail address: wahyudiapt2016@gmail.com
} 


\section{Introduction}

Acne Vulgaris (AV) is one of the most common dermatologic conditions. Prevalence varies based on age and ethnicity, but up to $85 \%$ of adolescents and up to two-thirds of patients over the age 18 years old may be afflicted with acne Acne Vulgaris [1]. Moderate to severe acne greatly affects the quality of life with reduced self-esteem, marred physical appearance and less social relationships with others [2].The bacteria that cause acne consist of Propionibacterium acnes, Staphylococcus aureus, Staphylococcus epidermis. In addition to the psychological and occupational impairments listed, Acne Vulgaris has a major impact on self-esteem and self-image.Self-esteem is defined as "the reasonable or justifiable sense of one's worth or importance" [3]. African leaves (Gymnanthemum amygdalinum Del. Sch. Bip. Ex Walp), commonly called bitter leaf in England, are often used traditionally to treat fever, hiccups, kidney disease, diabetes, diarrhea, antimalarial, antimicrobial, antiviral, analgesic, antifungal, antihelmic, anticancer, antioxidant and eliminate acne.

Gymnanthemum amygdalinum used in this study as sample. African leaves (Gymnanthemum amygdalinum Del. Sch. Bip. Ex Walp) have various secondary metabolites including antraquinone, tannin, flavonoids, alkaloids, saponins, cardiac glycosides and triterpenes. Strong antimicrobial activity (Gymnanthemum amygdalinum Del. Sch. Bip ex Walp) due to bioactive content such as alkaloids, saponins, tannins, flavonoids, and triterpenoids [4].The tropical Africa species of Gymnanthemum have been treated and most of the South African species were treated. No complete treatment of the genus exists for Southern Africa, although the necessary combinations for most of the species from the subcontinent, with one additional species recently described [5]. Elaeis guineensis Jacq plant will be used as sample in this study. Elaeis guineensis (Palm) leaves contain compounds luteolin and chyrysoeriol. Luteolin is one of the specific members of the broader category of plant compounds known as flavonoids, which have antibacterial activity by reducing the synthesis of nucleic acids and proteins. Luteolin compounds have high antibacterial activity against gram-positive bacteria because luteolin has hydroxyl group that is responsible for antimicrobial activity. Palm plants are cultivated in different tropical areas such as Malaysia, Thailand, Africa and South Africa. Palm leaves are abundantly released as waste products from oil palm industries. Aqueous and alcoholic extracts of oil palm leaves have rich sources of polyphenols, antioxidants, flavonoids and catechins [6].

This research combines 2 types of plant extracts namely African leaves and palm leaves in order to get an anti-bacterial effect that causes acne which is far more effective than in a single form. The combination of the two plant extracts is then formulated in the form of a topical cream to easily aplly on the face skin, besides the cream form including preparations preferred by many people. Propionibacterium acnes is a Gram positive bacillus that is part of the human ecosystems $\mathrm{P}$ acnes 
resides in pilosebaceous follicles of the skin, colonizing the lipid-rich sebaceous glands. As an opportunist, P. acnes is well recognized as being involved in the inflammation process of acne vulgaris common skin disorder that affects most individuals at some point in their life and other chronic diseases. More recently, it has become recognized as the cause of foreign-body infections [7]. P. acnesis involved in the development of inflammatory acne by activating complements and metabolizing sebaceous triglycerides into fatty acids that irritate the follicular wall and surrounding dermis. It also produces exoenzymes and chemotactically attracts neutrophils. P. acnes produces lipases, proteases, andhydrolases, contributing to inflammation and tissue destruction; they express stress proteins which are responsible for comedonal rupture; and also incites an inflammatory response by acting on TLR-2. It may stimulate cytokines expressions, such as IL-6 and IL-8 by follicular keratinocytes and IL-8 and IL-12 in macrophages, which is thought to activate hyperkeratinization, cell adhesion, follicular obstruction, and inflammation. The sequential phenomena lead tovascular and cellular events of inflammatory response and cause follicular disruption giving rise to acne form lesions in the form of papules, pustules, and nodule [8]. This study uses 2 bacteria above with the aim to testing the effectiveness of anti-acne, because the two bacteria mentioned above are among the bacteria that cause acne.

In 2016, the World Health Organization published a fact sheet demonstrating that antibiotic resistance is a considerable threat to global health; it can affect anyone, any age and any country. Misuse of antimicrobial agents is a significant cause of antibiotic resistance, which leads to increased medical expenses and mortality [9]. Staphylococcus spp. are common commensally bacteria that colonize human skin and have been isolated from diverse sources such as meat, milk, cheese, soil, sand, sea water, freshwater, dust, and air S. epidermis is frequently isolated from the axillae, head, nares and epithelial tissues and it has been suggested that $\mathrm{S}$. epidermis may prevent the colonization of several pathogenic microorganisms such as Staphylococcus aureus [10].

\section{Materials and Methods}

The research type in this study was experimental. This study included several stages: sample preparation and making Ethanolic Extract of African Leaves (EEAL) and Ethanol Extract of Palm Leaves (EEPL), cream preparation formulations, evaluation and test for anti-bacterial activity cream preparations against the bacteria of Propionibacterium acne and Staphylococcus epidermis disk diffusion test, and irritation test.

\subsection{Sample Preparation and Extraction}

African leaf and palm oil leaf samples are cleaned of attached dirt by washing with running water, drained, then weighed wet weight and dried in a drying cup at a temperature of $40-50^{\circ} \mathrm{C}$ until the sample is dry. Samples are considered dry when they are fragile (crushed to be crushed), then sorted 
dry and the dry weight of the sample is weighed, then the sample is blended to powder and weighed. Simplisia powder is stored in a tightly closed plastic bag. $600 \mathrm{~g}$ of simplicia powder were put into a dark glass container then macerated with 7.5 parts of $96 \%$ ethanol (4.5 liters) of ethanol for 5 days protected from sunlight while stirring frequently, after 5 days the maceration results were filtered and squeezed with a flannel cloth then the residue is added to a sufficient amount of liquid so that the whole maserat is obtained as much as 6 liters, then allowed to stand for 2 days and pour it in. The maserat is evaporated with the help of a rotary evaporator at a temperature of no more than $70^{\circ} \mathrm{C}$ and then evaporated on a water bath until a thick extract is obtained.

\subsection{Cream Formulation}

The cream was typed oil in water $(\mathrm{o} / \mathrm{w})$, basic formula for cream [11].

\begin{tabular}{|c|c|c|}
\hline $\mathrm{R} /$ & Stearic Acid & $12 \mathrm{~g}$ \\
\hline & Setil alcohol & $0.5 \mathrm{~g}$ \\
\hline & Propylene glycol & $3 g$ \\
\hline & Triethanolamine & $1 \mathrm{~g}$ \\
\hline & Glycerin & $1-5$ drops \\
\hline & Sodiummetasulfite & $2 \%$ \\
\hline & Distilled water is & ad $100 \mathrm{~m}$ \\
\hline
\end{tabular}

The designs of cream preparation formulas contain a combination of ethanol extract of African leaves (EEAL) and palm oil leaves (EEPL). The cream formulas which used in this study can be seen in Table1 below.

Table 1. Cream Formula of EEAL and EEPL

\begin{tabular}{llcc}
\hline & Cream base $(\mathrm{g})$ & EEAL $(\mathrm{g})$ & EEPL $(\mathrm{g})$ \\
\hline F1 & $100 \mathrm{~g}$ & - & \\
\hline F2 & $90 \mathrm{~g}$ & $5 \mathrm{~g}$ & $5 \mathrm{~g}$ \\
\hline F3 & $80 \mathrm{~g}$ & $10 \mathrm{~g}$ & $10 \mathrm{~g}$ \\
\hline F4 & $60 \mathrm{~g}$ & $20 \mathrm{~g}$ & $20 \mathrm{~g}$ \\
\hline
\end{tabular}

Information:

F 1: cream base without African ethanol and leaf extract and palm oil leaves

F 2: cream preparations with 5\% African leaf ethanol extract (EEAL) and extract palm oil leaf ethanol (EEPL) 5\%

F 3: cream preparations with African leaf ethanol extract (EEAL) 10\% and palm oil leaf ethanol extract (EEPL) 10\% 
F 4: cream preparations with African leaf ethanol extract (EEAL) $20 \%$ and palm oil leaf ethanol extract (EEPL) 20\%

Ethanol extract of African leaves and leaves Palm oil is crushed in mortar, then added the base of the cream little by little and crushed them until homogeneous. Azelaic acid (zalface CR 20\%) is used as a comparison

\subsection{Microbiology Test}

Microbiological tests determine the antibacterial activity of African leaf ethanol cream preparations and palm leaves were carried out using the disc diffusion method, by measuring the diameter of bacterial growth barriers to the bacteria Propionibacterium acne and Staphylococcus epidermidis bacteria around reserve paper.

\subsection{Irritation Test For Volunteers}

An irritation test is carried out by applying a test preparation on the normal skin of a human panel to find out whether the preparation can cause irritation to the skin or not. The technique used in the irritation test was an open patch test on the inner forearm of 10 volunteers. The open patch test was carried out by applying preparations made at a specific area of attachment $(2.5 \times 2.5 \mathrm{~cm})$; it is left open and observed what happened. This test is carried out 3 times a day for 2 consecutive days [12]. The reaction observed was the occurrence of erythema and edema. According to Barel, Marc and Howard (2001), the primary irritation index with the Federal Hazardous Substance Act score of erythema and edema. No erythema edema (0), Very little erythema edema (1), little erythema edema (2), moderate erythema edema (3), very severe erythema and edema (4). Irritation test panelist criteria is a woman, age between 20-30 years, she is being physically and mentally healthy, she does not have a history of allergic diseases and declares her willingness to be an irritation test panelist. The number of volunteers in this study were as many as 10 people with ages 16 to 30 years [13].

\section{Results And Discussion}

\subsection{Irritation Test For Volunteers}

Skin irritation tests conducted to determine the occurrence of side effects caused by the preparation on the skin, by using cosmetics at the bottom of the arm or behind the ear. Judging from the results of the irritation test carried out in the absence of side effects in the form of erythema and edema on the skin, it indicates the preparation does not irritate the skin. 
Table 2. Result of irritation test

\begin{tabular}{lcccccccccc}
\hline Reaction & \multicolumn{1}{c}{ Volunteer Number } \\
\cline { 2 - 11 } & 1 & 2 & 3 & 4 & 5 & 6 & 7 & 8 & 9 & 10 \\
\hline Erythema & 0 & 0 & 0 & 0 & 0 & 0 & 0 & 0 & 0 & 0 \\
\hline Edema & 0 & 0 & 0 & 0 & 0 & 0 & 0 & 0 & 0 & 0 \\
\hline
\end{tabular}

This irritation test is performed on all topical anti-acne cream preparations. test results showed that all anti-acne topical cream preparations did not show the occurrence of irritation to the volunteer skin

\subsection{The results of the antibacterial activity}

Propionibacterium acne

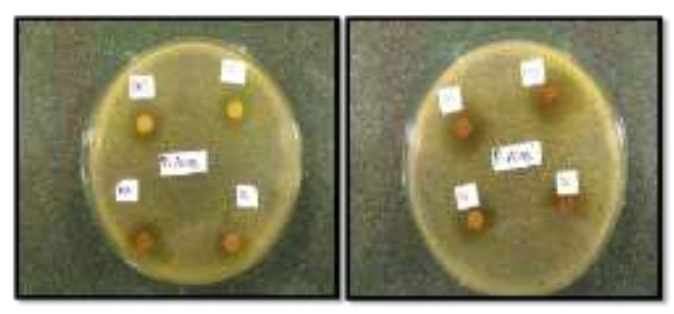

Stapylococus epidermis
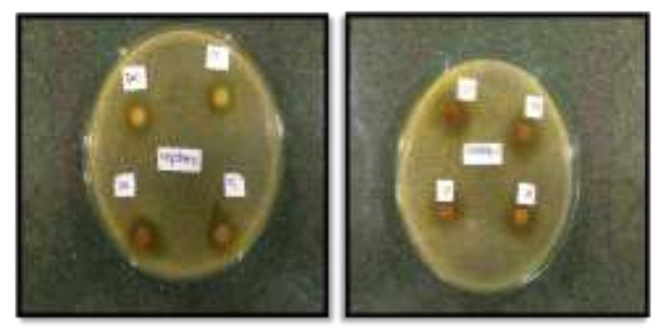

Figure 1. Result of effectivity EEAL and EEPL cream to inhibit the bacterial cause acne vulgaris.

Antibacterial activity testing of African leaf ethanol extract cream was carried out on four formulas and comparison with the disc diffusion method against the bacteria Propionibacterium acne and Staphylococcus epidermidis bacteria. Results can be seen below: 
Table 3. Result of Bacterial inhibition

\begin{tabular}{|c|c|c|}
\hline \multirow{2}{*}{ Formulation } & \multicolumn{2}{|c|}{ Bacterial inhibiton (mm)* } \\
\hline & Propionibacterium acne & Staphylococus epidermis \\
\hline F1 & - & - \\
\hline $\mathrm{F} 2$ & 12,06 & 13,63 \\
\hline F3 & 16,36 & 17,06 \\
\hline $\mathrm{F} 4$ & 18,56 & 19,83 \\
\hline Zelface cream & 20,43 & 23 \\
\hline
\end{tabular}

Information:

F 1: cream base without African ethanol and leaf extract and palm oil leaves

F 2: cream preparations with 5\% Ethanol Extract African Leaf (EEAL) and Ethanol Extract Palm oil Leaf (EEPL) $5 \%$

F 3: cream preparations with Ethanol Extract African Leaf (EEAL) 10\% and Ethanol Extract Palm oil Leaf (EEPL) $10 \%$

F 4: cream preparations with Ethanol Extract African Leaf (EEAL) 20\% and Ethanol Extract Palm oil Leaf (EEPL) 20\%

Topical or/and systematic treatments are used to treat acne. The response of patients to treatment is considerably different. It is usually more than one treatment modality employed to treat acne and the best results achieved when treatments are individualized based on clinical evaluations. Retinoids are the mainstay of therapy in patients who only have comedones. They are capable of reducing inflammatory lesions and the number of comedones (40\% - 70\%). Other agents, including isotretinoin, oral antibiotics, topical antimicrobials, and hormonal therapy, have been shown to yield high response rates. Patients with mild to moderate severity, inflammatory acne with papules and pustules are recommended to be treated with topical antibiotics combined with retinoids. For patients with moderate to severe inflammatory acne, oral antibiotics are the first-line therapy and medicinal plants are also used for the treatment of acne [14].

Staphylococcus aureus and Propionibacterium acnes have been attributed to acne vulgaris. However, their exact contributions to the acne process are not entirely clear. There are sub-strains of $P$. acnes in normal skin and some others in long-term acne complications. Therefore, it is unclear whether these strains are involved in this condition or they are pathogenically acquired. The resistance of P. acnes to commonly used drugs is increasing. These strains can change, perpetuate, or adapt to the abnormal oil production, inflammation and inadequate sloughing of acne pores. Infection with Demodex, which is 
a parasitic mite is associated with the development of acne. However, eradication of the mites has not improved acnes [15].

Leaf extracts of V. amygdalina have been screen for phytochemicals and bacterial growth inhibition potentials. The methanolic and ethanolic leaf extracts were found to contain significant quantities of bioactive agents. The methanolic leaf extract of V. amygdalina was found to possess broad- spectrum growth inhibitory activity against beta-lactamase-producing bacteria such as S. aureus, K.pneumonia, P. aeruginosa and E. coli in vitro. This justifies the use of the plant in folkloric medical practices in the treatment of a range of infections caused by these bacteria. We conclude that methanolic leaf extract of V. amygdalina is a potential candidate for subsequent isolation of effective antibacterial agent for the treatment of infections caused by beta-lactamase- producing bacteria. However, a wider study with an increase in number of clinical isolates and the identification of the active compounds in the crude extract is desired. The presence of numerous compounds in a crude extract may interfere with the activity of the active compounds hence work on separation of compounds in the crude extracts is underway. Further work on vivo antibacterial potentials of the extracts will also be undertaken.

The results of this study show that F1, F2, F3 and F4 has effective to inhibit the bacterial, Propionibacterium acne and Staphylococus epidermis bacterial who can cause acne vulgaris, so inhibition of both bacterial can inhibit the development of acne vulgaris. The results of this study are in accordance with the Wikaningtyas study (2016), that the content of secondary metabolites in plants such as alkaloids and others can inhibit bacterial growth. the anti-bacterial effect of the cream can inhibit the growth / killing of bacteria, it can be seen from its inhibition which is comparable to the positive control [16].

\section{Conclusion}

All of the topical creams from a combination extract of Gymnanthemum amygdalinum Del. and Elaeis guineensis Jacq. have anti-acne activity and the F4 is the most effective concentration creams.

\section{Acknowledgement}

The authors are gratefully thank to Faculty of Pharmacy Deli Husada Health Institute for providing the facilities.

\section{REFERENCES}

[1]. S. M. Gallitano and D. S. Berson, "How Acne Bumps Cause the Blues: The Influence of Acne Vulgaris on Self-Esteem," International Journal of Women's Dermatology, vol. 4, no. 1, pp. 12-17, 2018. 
[2]. E. Tasoula, S. Gregoriou, J. Chalikias, D. Lazarou, I. Danopoulou, A. Katsambas, and D. Rigopoulos, "The impact of acne vulgaris on quality of life and psychic health in young adolescents in Greece: results of a population survey," Anais Brasileiros de Dermatologia, vol. 87, no. 6, pp. 862-869, 2012.

[3]. M. Webster, "Self-esteem", 2017. [Online].Available: https://www.merriamwebster.com/dictionary/ self-esteem;

[4]. P. Praptiwi, A. Fathoni, and M. Ilyas, "Diversity of endophytic fungi from Vernonia amygdalina, their phenolic and flavonoid contents and bioactivities," Biodiversitas Journal of Biological Diversity, vol. 21, no. 2, Jan. 2020.

[5]. N. Swelankomo, J. C. Manning, and A. R. Magee, "The genus Gymnanthemum Cass. (Asteraceae: Vernonieae) in Southern Africa," South African Journal of Botany, vol. 102, pp. 81-101, Jan. 2016.

[6]. T. Ahmad, M. Irfan, and S. Bhattacharjee, "Parametric Study on Gold Nanoparticle Synthesis Using Aqueous Elaise Guineensis (Oil palm) Leaf Extract: Effect of Precursor Concentration," Procedia Engineering, vol. 148, pp. 1396-1401, 2016.

[7]. C. Feuillolay, S. Pecastaings, C. L. Gac, C. Fiorini-Puybaret, J. Luc, P. Joulia, and C. Roques, "A Myrtus communis extract enriched in myrtucummulones and ursolic acid reduces resistance of Propionibacterium acnes biofilms to antibiotics used in acne vulgaris," Phytomedicine, vol. 23, no. 3, pp. 307-315, Mar. 2016.

[8]. S. Priyam., S.Shruti., M. Nidhi., and P.Y. Narayan, "New Perspectives on Anti acne Plant Drugs: Contribution to Modern Therapeutics", BioMed Research International.2014

[9]. World Health Organization, "Antibiotic resistance" 2016 [Online]. Available: http://www.who.int/mediacentre/factsheets/antibiotic-resistance/en/

[10]. M. G. Eladli, N. S. Alharbi, J. M. Khaled, S. Kadaikunnan, A. S. Alobaidi, and S. A. Alyahya, "Antibiotic-resistant Staphylococcus epidermidis isolated from patients and healthy students comparing with antibiotic-resistant bacteria isolated from pasteurized milk," Saudi Journal of Biological Sciences, vol. 26, no. 6, pp. 1285-1290, Sep. 2019.

[11]. A. Young., Practical Cosmetic Science, Mills and Boon Limited, London. 1972

[12]. 12.R.I.Tranggono,dan L. Fatma, Buku Pegangan Ilmu Pengetahuan Kosmetik. Jakarta: Gramedia Pustaka Utama: Halaman 11, 20-21, 26-27, 131. 2007

[13]. A.O. Barel, P. Marc, and I,M, Howard. Handbook of Cosmetics Science and Technology. New York: Informa Health Care, p 471-473. 2001

[14]. H. Nasri, M. Bahmani, N. Shahinfard, A. Moradi Nafchi, S. Saberianpour, and M. Rafieian Kopaei, "Medicinal Plants for the Treatment of Acne Vulgaris: A Review of Recent Evidences," Jundishapur Journal of Microbiology, vol. 8, no. 11, Nov. 2015.

[15]. M. Bek-Thomsen, H. B. Lomholt, and M. Kilian, "Acne is Not Associated with Yet-Uncultured Bacteria," Journal of Clinical Microbiology, vol. 46, no. 10, pp. 3355-3360, Aug. 2008. 